\title{
Psychological Factors as Predictors of Suicide Ideation among Police Officers in Police Training Schools in the South-South Geopolitical Zone of Nigeria: Educational Implications
}

\author{
Achonwa Uchenna, Charles*, Dr. Jerry Odiase, Dr. Glory N. Amadi \\ Department of Educational Psychology Faculty of Education University of Port Harcourt \\ *Corresponding Author: Achonwa Uchenna, Charles, Department of Educational Psychology Faculty \\ of Education University of Port Harcourt, Nigeria
}

\begin{abstract}
The study investigated psychological factors (anxiety and depression) as predictors of suicide ideation among Police Officers in Police Training Colleges in the South-South Geopolitical Zone of Nigeria. Two research questions were raised and two hypotheses tested at 0.05 level of significance. A sample size of 3,373Police Officers in training in four Police Training Colleges in the South-South Geopolitical Zone of Nigeria was randomly selected through simple random sampling technique. Multiple Prediction Design of Correlational Research Method was used for the investigation, while Linear Regression was used for the entire analyses and hypotheses testing. The result showed that there is a significant relationship between psychological factors (anxiety and depression) and suicide ideation of Police Officers in Police Training Colleges; also the result showed that there is a very low positive relationship between anxiety and depression as predictors of suicide ideation among Police Officers in Police Training Colleges in the South-South Geopolitical Zone of Nigeria. The result also suggests more especially to counseling psychologists that among other variables, anxiety and depression are some of the predictive variables of suicide ideation. Recommendations were made.
\end{abstract}

\section{INTRODUCTION}

Suicide is a significant public health problem that touches people from all backgrounds. The impact of suicide is far reaching emotionally and economically, affecting families, friends, co-workers and many others. Briefly defined, suicide is the human act of self-inflicted, self-intentioned cessation (Shneidman, 1973). It is the intentional taking away of one's life by one's own hands. Suicide is not a disease (although there are many who think so); it is not a biological anomaly (although biological factors may play a role in some suicides); it is not an immorality (although it has often been treated as such); and it is not a crime in most countries around the world (although it was so for centuries). Suicide occurs in every country in the world and among all racial and ethnic groups. Being destitute and alone increases the risk of suicide, but suicide occurs in all groups of the population, the young and the old, the rich and the poor, the famous and those who remain unnoticed. For each suicide death that occurs, there are many more nonfatal suicide acts ranging in seriousness from mild overdoses and superficially inflicted cuts to potentially lethal acts such as jumping from a high place or ingesting a corrosive poison.

It might be very possible that one of the reasons why some Nigerians now take their own lives could be based on the nation's present socio-economic environment, which is a predisposing index to depression and perhaps suicide. Since there is enormous emotional and financial stress as well as pervading poverty and hopelessness everywhere, there is also need for the authorities to begin to examine some of the situations with a view to finding remedies for them.

Center for Disease and Control and Prevention Statistics Department (2010) reported that in 2010 more than 38,000 people died by suicide. Similarly, Substance Abuse and Mental Health Services Administration (2011) also affirmed that more than one million adults were reported making suicide attempts and more than eight million adults seriously thought about attempting suicide.

Anxiety is regarded as a general term for several disorders that cause nervousness, fear, apprehension and worry (Bouras and Holt, 2007). Onyekuru and Opara (2015) defined anxiety as an unpleasant 
state of inner turmoil often accompanied by nervous behavior, such as pacing back and forth, somatic complaint and rumination. An anxiety disorder is one of the most common mental health problems among individuals (Mash and Wolfe, 2003). Every person experiences fear, worry or anxiety as a normal part of life, but each person suffers from an anxiety disorder that is excessive and debilitating. It is a feeling of worry, dread, and uneasiness which people have as a result of over-reaction to a situation that is subjectively seen as menacing. Anxiety when it is mild is normal and helps to invigorate an individual and prepares the body physically, cognitively and behaviourally to detect and deal decisively with threats to survival. However, severe anxiety can be extremely debilitating, having serious impact on the daily lives of individuals. Recently, Tsokar (2016) reported in the Guardian the action of the Acting Inspector General of Police, Mr. Ibrahim Idris of swearing in new management as capable of generating anxiety within the ranks of the Nigeria Police Force. Anxiety could thrill the air as officers and men see their colleagues promoted, demoted or even killed.

Depression is a common mental disorder that presents with depressed mood, loss of interest or pleasure, decreased energy, feelings of guilt or low self-worth, disturbed sleep or appetite, and poor concentration. Moreover, depression often comes with symptoms of anxiety. These problems can become chronic or recurrent and lead to substantial impairments in an individual's ability to take care of his or her everyday responsibilities. At its worst, depression can lead to suicide. Almost one million lives are lost yearly due to suicide, which translates to 3000 suicide deaths every day. For every person who completes a suicide, 20 or more may attempt to end his or her life (WHO, 2012). A police officer diagnosed of Major Depression Disorder (MDD) will exhibit: sadness, loss of interest or pleasure in nearly all activities, irritability among others. These feelings are potent enough to trigger any form of suicide contemplation.

It is the purpose of this study to examine whether psychological factors (anxiety and depression) are predictors of suicide ideation among Nigeria Police officers in Training in Police Training Schools in South-South Geopolitical Zone of Nigeria. Specifically, the study intends to:

1. Examine whether anxiety predicts suicide ideation among police officers in training in Police Training Schools in South-South Geopolitical Zone of Nigeria.

2. Ascertain whether depression predicts suicide ideation among police officers in training in Police Training Schools in South-South Geopolitical Zone of Nigeria.

The following research questions guided the study:

1. To what extent does anxiety predict suicide ideation among Police officers in training in Police Training Schools?

2. To what extent does depression predict suicide ideation among Police officers in Training in Police training Schools?

The following hypotheses were tested at .05 level of significance:

1. $\mathrm{HO}_{1} \quad$ Anxiety does not significantly predict suicide ideation and anxiety.

2. $\mathrm{HO}_{2} \quad$ Depression does not significantly predict suicide ideation.

\section{Methodology}

The study examined psychological factors (anxiety and depression) as predictors of suicide ideation among Police Officers in Police Training Colleges in the South-South Geopolitical Zone of Nigeria. It is a correlational study. The predictor variables of the study are anxiety and depression, while suicide ideation is the criterion variable.

A sample of 3, 373 Police Officers from four Police Training Colleges in the South-South Geopolitical Zone of Nigeria were randomly selected using the simple random sampling technique. Four questionnaires: Becks Anxiety Inventory (BAI) and Beck's Depression Inventory (BDI), and Suicide Behaviors Questionnaire - Revised (SBQ - R), whose reliability co-efficients are 0.50, 0.90 and 0.71 respectively, were used to obtain information about the Officers' anxiety level, depression level and suicide ideation. The data collected were analyzed using Linear Regression. The hypotheses were tested accordingly. The results were presented in line with the research questions and hypotheses: 
Psychological Factors as Predictors of Suicide Ideation among Police Officers in Police Training Schools in the South-South Geopolitical Zone of Nigeria: Educational Implications

Table1. Linear Regression analysis showing the extent to which anxiety predicts suicide ideation among Police officers in Police Training Colleges in South-South Geo-Political Zone of Nigeria

\begin{tabular}{|c|c|c|c|c|c|c|c|c|c|}
\hline & \multirow[b]{2}{*}{$\mathbf{R}$} & \multirow[b]{2}{*}{$\mathbf{R}^{2}$} & \multirow[b]{2}{*}{$\begin{array}{l}\text { Adj. } \\
\mathbf{R}^{2}\end{array}$} & \multirow[b]{2}{*}{ Std Error } & \multicolumn{2}{|c|}{$\begin{array}{l}\text { Unstandardized } \\
\text { Coefficients }\end{array}$} & \multirow{2}{*}{$\begin{array}{c}\begin{array}{c}\text { Standardized } \\
\text { Coefficients }\end{array} \\
\text { Beta }\end{array}$} & \multirow[b]{2}{*}{$\mathbf{t}$} & \multirow[b]{2}{*}{ Sig. } \\
\hline & & & & & B & Std Error & & & \\
\hline (Constant) & .023 & .001 & .000 & 2.368 & 7.240 & .080 & $\begin{array}{l}-023 \\
\end{array}$ & 90.429 & .000 \\
\hline Anxiety & & & & & -.005 & .004 & & & \\
\hline
\end{tabular}

Table 1 shows the model summary. Here the independent regression coefficient (R) for anxiety is .023. The coefficient of determination $\mathrm{R}^{2}$ for anxiety is .001 . The Adjusted $\mathrm{R}$-square for anxiety is .000. The standard error of estimate is shown to be 2.368 and $\beta, 7.240$. The correlation coefficient between anxiety and suicide ideation among Police officers in Police Training Colleges in SouthSouth Geo-Political Zone of Nigeria is 0.023 , revealing a low relationship. The coefficient of determination is .001 ; this shows that $0.1 \%$ of the variance in suicide ideation among Police officers in Rivers State is accounted for by anxiety. The Beta value reveals that as the values of anxiety increases or decreases by a unit, there will be a corresponding 7.240 increase or decrease in the values of suicide ideation among Police officers in Police Training Colleges in South-South Geo-Political Zone of Nigeria. In other words a unit variation in anxiety will result in $7.24 \%$, variation in suicide ideation among Police officers in the South-South Geo-Political Zone of Nigeria.

Furthermore, anxiety was found to be a significant predictor of suicide ideation among police officers in the South-South Geo-Political Zone of Nigeria [ $\mathrm{t}=90.429$; $\mathrm{p}<.01$ ); hence the null hypothesis which states that anxiety does not predict suicide ideation among Police officers in Police Training Colleges in South-South Geo-Political Zone of Nigeria is rejected and the alternate hypothesis is accepted.

Information from the table shows that where anxiety was the predictor variable, the regression constant $(\mathrm{B})$ is 7.240 , while the unstandardized regression coefficient is -.005 . Thus the simple linear equation to predict suicide ideation from anxiety would be; $\mathrm{Y}=7.240+(-.005) \mathrm{X}$. Where $\mathrm{Y}$ is the predicted score of suicide ideation and $\mathrm{X}$ is any given score for anxiety. That means, suicide ideation $=7.240+(-.005)$ anxiety.

Table2. Linear Regression analysis showing the extent to which depression predict suicide ideation among Police officers in Police Training Colleges in South-South Geo-Political Zone of Nigeria

\begin{tabular}{|c|c|c|c|c|c|c|c|c|c|}
\hline & \multirow[b]{2}{*}{$\mathbf{R}$} & \multirow[b]{2}{*}{$\mathbf{R}^{2}$} & \multirow[b]{2}{*}{$\begin{array}{l}\text { Adj. } \\
\mathbf{R}^{2}\end{array}$} & \multirow[b]{2}{*}{$\begin{array}{l}\text { Std } \\
\text { Error }\end{array}$} & \multicolumn{2}{|c|}{$\begin{array}{c}\text { Unstandardized } \\
\text { Coefficients }\end{array}$} & \multirow{2}{*}{$\begin{array}{c}\begin{array}{c}\text { Standardized } \\
\text { Coefficients }\end{array} \\
\text { Beta }\end{array}$} & \multirow[b]{2}{*}{$\mathbf{t}$} & \multirow[b]{2}{*}{ Sig. } \\
\hline & & & & & B & Std Error & & & \\
\hline (Constant) & \multirow[t]{2}{*}{.185} & \multirow[t]{2}{*}{.034} & \multirow[t]{2}{*}{.034} & \multirow[t]{2}{*}{2.328} & 6.245 & .092 & \multirow[t]{2}{*}{.185} & \multirow[t]{2}{*}{67.962} & \multirow[t]{2}{*}{.000} \\
\hline Depression & & & & & .036 & .003 & & & \\
\hline
\end{tabular}

Table 2 shows the model summary. Here the independent regression coefficient $(\mathrm{R})$ for depression is .185. The coefficient of determination $\mathrm{R}^{2}$ for depression is .034. The Adjusted $\mathrm{R}$-square for depression is .034. The standard error of estimate is shown to be 2.328 and $\beta, 6.245$. The correlation coefficient between depression and suicide ideation among Police officers in Police Training Colleges in SouthSouth Geo-Political Zone of Nigeria is 0.185 , revealing a low relationship. The coefficient of determination is .034; this shows that $3.4 \%$ of the variance in suicide ideation among Police officers in Rivers State is accounted for by depression. The Beta value reveals that as the values of depression increases or decreases by a unit, there will be a corresponding 6.245 increase or decrease in the values of suicide ideation among Police officers in Police Training Colleges in South-South Geo-Political Zone of Nigeria. In other words a unit variation in depression will result in $6.25 \%$, variation in suicide ideation among Police officers in the South-South Geo-Political Zone of Nigeria.

Furthermore, depression was found to be a significant predictor of suicide ideation among police officers in the South-South Geo-Political Zone of Nigeria $[\mathrm{t}=67.962 ; \mathrm{p}<.01$ ); hence the null hypothesis which states that depression does not predict suicide ideation among Police officers in Police Training Colleges in South-South Geo-Political Zone of Nigeria is rejected and the alternate hypothesis is accepted. 
Information from the table shows that where depression was the predictor variable, the regression constant (B) is 6.245, while the unstandardized regression coefficient is .036. Thus the simple linear equation to predict suicide ideation from depression would be; $\mathrm{Y}=6.245+(.036) \mathrm{X}$. Where $\mathrm{Y}$ is the predicted score of suicide ideation and $\mathrm{X}$ is any given score for depression. That means, suicide ideation $=6.245+(.036)$ depression .

\section{DISCUSSION}

The findings of this study indicate that anxiety is significant predictor of suicide ideation among police officers in training in Police Training Schools in South-South Geopolitical Zone of Nigeria.

The statistic result shows a low positive relationship between anxiety and suicide ideation among police officers in police training colleges, exemplified by the correlation coefficient of 0.023 . The results from the Beta values also indicate very clearly that any unit increase or decrease in the anxiety level of police officers in police training colleges in the south-south geopolitical zone of Nigeria, results in a 7.240 increase or decrease in their suicide ideation. This indicates that anxiety is a significant predictor among police officers in police training colleges in the south-south geopolitical zone of Nigeria.

This result agrees with the findings of the study conducted by Izadiniaa, Amiria, Jahromia, Hamidia (2010), which explored the relationship between suicide ideas, depression, anxiety, resiliency, daily stresses and mental health among Tehran university students. 265 students of Tehran University were studied. Suicide ideation had a significant and negative relationship with resiliency. Anxiety, depression, mental health and daily stresses had a positive relationship with suicide ideation. Regression analysis revealed that depression had the most contribution in predicting suicide ideation while anxiety, mental health, Resiliency, and daily stresses were the next contributing factors, respectively. These variables could predict 21 percent of suicide ideation altogether. Psychological problems and mental health issues and other factors such as resiliency and daily stresses play an important role in suicide ideation.

The result of the study also shows that depression is a significant predictor of suicide ideation among police officers in training in Police Training Schools in South-South Geopolitical Zone of Nigeria. The statistic result also shows a correlation coefficient of 0.185 between depression and suicide ideation which indicates low positive relationship between depression and suicide ideation among police officers in police training colleges. The results from the Beta values also indicate very clearly that any unit increase or decrease in the anxiety level of police officers in police training colleges in the south-south geopolitical zone of Nigeria, results in a 6.245 increase or decrease in their suicide ideation. This indicates that depression is a significant predictor among police officers in police training colleges in the south-south geopolitical zone of Nigeria.

This result clearly agrees with the findings of the study carried out by Izadiniaa, Amiria, Jahromia, Hamidia (2010), which explored the relationship between suicide ideas, depression, anxiety, resiliency, daily stresses and mental health among Tehran university students. Regression analysis revealed that depression had the most contribution in predicting suicide ideation while anxiety, mental health, Resiliency, and daily stresses were the next contributing factors, respectively.

\section{CONCLuSion}

The study focused on psychological factors (anxiety and depression) as predictors of suicide ideation among police officers in police training colleges in the south-south geopolitical zone of Nigeria. A total number of 3, 373 police officers being trained in four (4) police training colleges in the southsouth geopolitical zone of Nigeria were used. With regards anxiety and depression, it was discovered that police officers with high anxiety and depression levels are most likely to experience high level of suicide ideation, while those with low levels of anxiety and depression are most unlikely to experience or express suicide ideation. Thus, the study reveals that psychological factors (anxiety and depression) are significant predictors of suicide ideation among police officers in training in police training colleges in the south-south geopolitical zone of Nigeria. 
Psychological Factors as Predictors of Suicide Ideation among Police Officers in Police Training Schools in the South-South Geopolitical Zone of Nigeria: Educational Implications

\section{RECOMMENDATIONS}

The following recommendations were made from the study:

1. Since anxiety and depression are significant predictors of suicide ideation, officers and men of the Nigeria Police being recruited at all levels, should be mandatorily subjected to a thorough psychological evaluation, to ascertain their anxiety and depression status, before any form of training; for a more professional and impactful result.

2. Personnel training and re-training that integrates relevant psychological matters should be mandatorily introduced into the Nigeria Police, to keep the officers and men of the Nigeria Police abreast of the trends in the prediction of suicide ideation, so as to be able to identify any significant increase in the predictors and manage it effectively.

3. Professional psychologists/psychotherapists should be employed and posted to every Police Divisional Headquarters in Rivers State, to provide psychological assistance to officers and men of the Nigeria Police experiencing suicide tendencies or exhibiting behaviours suggestive of suicide ideation.

\section{REFERENCES}

Akrani, G. (2011, March 27). Frustration - Types of Reaction and Causes of Frustration. http://kalyancity.blogspot.com.ng/2011/03/frustration-types-of-reaction- and.html

Bouras, N., \& Holt, G. (2007). Psychiatric behavioral disorder in intelligence and development disabilities $\left(2^{\text {nd }}\right.$ ed.). Cambridge University Press.

Izadinia, N., Amiri, M., Jahromi, R.G. and Hamidi, S. (2010). "A study of relationship between suicidal ideas, depression, anxiety, resiliency, daily stresses and mental health among Tehran university students '.Procedia Social and Behavioral Sciences (5) 1515-1519.

Kisker, G. W. (1964). The disorganizedpersonality. McGraw-Hill.

Mash, E. J. and Wolfe, D. A. (2003). Disorders of Childhood and Adolescent. https://doi.org/10.1002/ 0471264385.wei0802

Muanya, C., \&Ezea, S. (2017, March 25). "Worrisome, rising cases of suicide in Nigeria". The Guardian Saturday Magazine. https://guardian.ng/saturday-magazine/.

Onyekuru, B. U. \&Opara, I. M. (2015). Relationship between test anxiety, locus of control and academic achievement among college students. European Scientific Journal.1 (5): 58 - 69.

Shneidman, E. (1973). Suicide. In Encyclopedia Britannica, Vol. 21, 383-385. Chicago: Williams Benton.

Tsokar, K. (2016, July 11). “Anxiety as IGP swears new management team”. The Guardian Saturday Magazine. https://guardian.ng/news/anxiety-as-igp-swears-in-new-management-team.

World Health Organization, World suicide prevention day 2012. http://www. who.int/mediacentre/events/ annual/world_suicide_prevention_day/en/Accessed 16.6.201

Citation: Achonwa Uchenna, Charles, et.al. " Psychological Factors as Predictors of Suicide Ideation among Police Officers in Police Training Schools in the South-South Geopolitical Zone of Nigeria: Educational Implications" International Journal of Humanities Social Sciences and Education (IJHSSE), vol 8, no. 7, 2021, pp. 12-16. doi: https://doi.org/10.20431/2349-0381.0807002.

Copyright: (C) 2021 Authors. This is an open-access article distributed under the terms of the Creative Commons Attribution License, which permits unrestricted use, distribution, and reproduction in any medium, provided the original author and source are credited. 